\title{
Identification of New Pathogenic Races of Common Bunt and Dwarf Bunt Fungi, and Evaluation of Known Races Using an Expanded Set of Differential Wheat Lines
}

\author{
Blair J. Goates, United States Department of Agriculture-Agricultural Research Service, Aberdeen, ID 83210
}

\begin{abstract}
Goates, B. J. 2012. Identification of new pathogenic races of common bunt and dwarf bunt fungi, and evaluation of known races using an expanded set of differential wheat lines. Plant Dis. 96:361-369.

Pathogenic races of Tilletia caries and T. foetida, which cause common bunt of wheat (Triticum aestivum), and Tilletia contraversa, which causes dwarf bunt of wheat, have been identified previously by their reaction to 10 differential wheat lines, each containing single bunt resistance genes Bt1 through Bt10. The reactions of races to the differential wheat lines follow the classic gene-for gene system for hostpathogen interactions. The pathogens are closely related and resistance to both diseases in wheat is controlled by the same genes. To better define pathogenic races, six additional wheat lines containing the genes Bt11 through Bt15 and a wheat line with a resistance factor designated as Btp were added to the set of 10 differentials and tested with all named U.S. races of common bunt and dwarf bunt. In addition, new isolates of dwarf bunt, and common bunt from hybrids and field collections, were tested with all 16 differentials for race identification. Six new races of $T$. caries, five new races of $T$. foetida, and two new races

$B t 8$ or $B t 12$, and dwarf bunt races virulent to the combinations of $B t 11$ and $B t 12$, and $B t 8, B t 9, B t 10, B t 11$, and $B t 12$, were identified for the first time. Comparison of the reactions of the common bunt races with the Bt14 and Bt15 differentials grown in different environments after initial infection showed that these genes are temperature sensitive, indicating they should be excluded from the set of differential lines to avoid ambiguity in determining virulent or avirulent reactions. In the previous list of bunt races, there were races that had the same reaction to the set of 10 differentials but were designated as different races. These races were not differentiated further with the six additional differentials, indicating that the duplicate races should be dropped from the list of pathogenic races. The new races of common bunt and dwarf bunt identified have unique patterns of virulence that allow specific targeting and elucidation of bunt resistance genes in wheat and will aid the development of bunt-resistant wheat cultivars.
\end{abstract} of $T$. contraversa were identified. Races of common bunt virulent to
Common bunt of wheat (Triticum aestivum L.) caused by Tilletia caries (DC.) Tul. \& C. Tul. (=T. tritici) and T. foetida (Wallr.) Liro (=T. laevis), and dwarf bunt of wheat caused by T. contraversa J.G. Kühn, have a classic gene-for-gene relationship between the host and pathogen $(17,25,34)$. The three bunt species have not been differentiated at the genetic level when a sufficient number of isolates is compared $(5,6)$. Additionally, the close genetic relationship of these three species is indicated by similar polypeptide patterns produced by two-dimensional polyacrylamide gel electrophoresis (29). The three bunt fungi are very closely related, to the extent that virulence in these fungi is regulated by the same set of bunt resistance genes in wheat $(25,34)$. Thus, resistance to common bunt also confers resistance to dwarf bunt. Common bunt is often used by breeders in initial screening of segregating lines for resistance to dwarf bunt because common bunt can be induced more reliably due to less stringent environmental requirements that are easily managed (17).

Despite the close relationship of the three Tilletia spp., common bunt and dwarf bunt are distinct diseases that have completely different etiologies and climatic requirements (17). T. contraversa teliospore germination requires several weeks of stable cool temperatures that are provided by continuous snow cover. Soilborne teliospores of $T$. contraversa germinate at the soil surface beneath snow during midwinter and produce hyphae that infect emerged seedlings. Seedborne teliospores of $T$. contraversa are essentially inconsequential to development of dwarf bunt (22). In contrast,

Corresponding author: B. J. Goates; E-mail: goatesfam@cableone.net

Accepted for publication 4 October 2011.

http://dx.doi.org/10.1094/PDIS-04-11-0339

This article is in the public domain and not copyrightable. It may be freely reprinted with customary crediting of the source. The American Phytopathological Society, 2012. common bunt is typically induced by seedborne teliospores that contaminate seed. Teliospores germinate within a few days after planting and produce hyphae that infect wheat coleoptiles prior to seedling emergence. Soilborne teliospore inoculum can also be important in common bunt infection. Inoculum can remain viable for 2 to 3 years; thus, sufficient time is needed between wheat crops in rotations to eliminate teliospore viability.

Even though common bunt and dwarf bunt can be effectively controlled with seed treatment fungicides, incorporating resistance into cultivars is still important in many wheat-breeding programs worldwide. Currently, host resistance has gained renewed interest with the increase in organic wheat production (33). Knowledge of bunt resistance genes in wheat and their reaction to races of the pathogens is essential to this effort.

A set of differential wheat lines has been used since the mid1940s to evaluate virulence characteristics of common bunt and dwarf bunt pathogens (36). More recently, pathogenic races of these bunt fungi are identified by the virulent or avirulent reactions to a set of putative monogenic differential wheat cultivars developed by R. J. Metzger and J. A. Hoffmann $(17,25,34)$. Races of $T$. caries, $T$. foetida, and $T$. contraversa are designated by the letters "T", "L", and "D", respectively, followed by a number to indicate the specific race. Thus far, there have been 30 races of $T$. caries, 10 races of $T$. foetida, and 17 races of $T$. contraversa identified based on their reactions to a set of 10 wheat differential cultivars containing the resistance genes Bt1 through Bt10 $(25,34)$.

The set of 10 differential lines used by Hoffmann and Metzger (25) has evolved and expanded over the years to include five additional wheat lines developed by R. J. Metzger that carry the resistance genes Bt11 through Bt15 (17). The Bt1 to Bt13 differentials are winter hexaploid wheat, whereas the Bt14 and Bt15 differentials are spring tetraploid (durum) wheat. In addition, the winter landrace PI 173437, which has a reaction to races that is independent of the other differentials, has been utilized and given the designation Btp (R. J. Metzger, personal communication). 
The set of 15 differential cultivars (Bt1 to Bt15) has been used throughout the world to evaluate the virulence characteristics of local wheat bunt isolates $(1-4,7-9,14,26,27,30,31,38,42)$. Virulence characteristics of common bunt fungi that are different than those in the United States have been reported occasionally $(1,8,27,38)$ and new pathotype designations have been suggested; however, these were based on limited testing or undefined methods $(1,4,9,27,31)$. The most notable difference between U.S. and nonU.S. isolates of common bunt is the virulence detected to Bt8 in Indian isolates (38) whereas no known natural collections of common bunt in the United States have virulence to this gene. Also, there are reports of some isolates that lack virulence to any of the differentials $(1,4)$. Finci (13) used a different set of differential cultivars and reported considerable variation of virulence characteristics in common bunt isolates from Turkey. Recently, a new virulence combination in $T$. caries has been identified in North America using the set of differentials with the resistance genes Bt1 to $\mathrm{Bt13}$ (32).

The last reports of pathogenic races of common bunt and dwarf bunt fungi in the United States were published in the 1970s and were based on the set of 10 differentials $(25,34)$. A summary of an unpublished preliminary study of the reaction of the common bunt races to the newer differentials Bt11 through Bt15 that was conducted by R. J. Metzger has been presented (17) but there is no information on the reaction of dwarf bunt races to these newer differentials, or on the reaction of common bunt races to Btp.

Testing new dwarf bunt and common bunt isolates in the United States for race identification declined after the retirement of J. A. Hoffmann and R. J. Metzger in mid-1980. However, the analysis of bunt isolates has continued in an effort to find isolates that have virulence characteristics that can assist in the elucidation of resistance genes effective against both common bunt and dwarf bunt. The objectives of this study were to analyze the reaction of the previously named pathogenic races of $T$. caries, $T$. foetida, and $T$. contraversa to an expanded set of bunt differentials, and to describe unique patterns of virulence of new bunt isolates to these differentials.

\section{Materials and Methods}

Wheat lines. Sixteen differential wheat lines that contain the bunt resistance genes $B t 1$ to $B t 15$ and Btp were used in this study (Table 1). The differentials with genes Btl through Bt13 and Btp are winter hexaploid wheat, whereas the differentials with Bt14 and $B t 15$ are spring tetraploid (durum) wheat. Seed of the wheat

Table 1. Wheat lines with specific bunt resistance genes $(B t)$ used to determine pathogenic races of common bunt and dwarf bunt fungi, and wheat lines with no known resistance genes that were used as positive controls

\begin{tabular}{lcc}
\hline Wheat line $^{\mathbf{a}}$ & Resistance gene & CI or PI number \\
\hline Red Bobs & None & CI 6255 \\
Heines VII & None & PI 209794 \\
Sel 2092 & $B t 1$ & PI 554101 \\
Sel 1102 & $B t 2$ & PI 554097 \\
Ridit & $B t 3$ & CI 6703 \\
CI 1558 & $B t 4$ & PI 11610 \\
Hohenheimer & $B t 5$ & CI 11458 \\
Rio & $B t 6$ & CI 10061 \\
Sel 50077 & $B t 7$ & PI 554100 \\
PI 173438/Eg & $B t 8$ & PI 554120 \\
Elgin/PI 178383 & $B t 9$ & PI 554099 \\
Elgin/PI 178383 & $B t 10$ & PI 554118 \\
Elgin/PI 166910 & $B t 11$ & PI 554119 \\
PI 119333 & $B t 12$ & PI 119333 \\
Thule III & $B t 13$ & PI 181463 \\
Doubbi & $B t 14$ & CI 13711 \\
Carleton & $B t 15$ & CI 12064 \\
PI 173437 & $B t p$ & PI 173437 \\
\hline
\end{tabular}

${ }^{a}$ Wheat lines are hexaploid winter growth habit except Red Bobs, which is a spring habit hexaploid, and Doubbi and Carleton, which are spring habit tetraploid (durum) originated from R. J. Metzger, who was primarily responsible for the development of the differentials. The winter wheat 'Heines VII' and spring wheat 'Red Bobs' were used as universally susceptible lines (designated in previous work as BtO) in fall-planted and spring-planted field nurseries, respectively, to indicate the disease pressure in each experiment. Red Bobs was most often used for tests conducted in the greenhouse because it is better adapted for growth under greenhouse conditions.

Pathogens. The bunt isolates used in this study consisted of (i) named pathogenic races of common bunt fungi T-1 through T-30 (T. caries) and L-1 through L-16 (T. foetida), and of dwarf bunt fungi D-1 through D-17 (T. contraversa), originating from the collections of R. J. Metzger, J. A. Hoffmann, and the author; (ii) domestic and international isolates of dwarf bunt and common bunt fungi from field collections; and (iii) isolates of common bunt fungi that were developed by R. J. Metzger from hybridizing known pathogenic races (Tables 2-5). The hybrids were developed by inoculating wheat seed with teliospores or, in some cases, compatible haploid cultures of two pathogenic races followed by selection for new combinations of virulence $(25,34)$. Some hybrids were virulent to certain bunt resistance genes even though neither parent was virulent to the genes. The mechanism for this has not been studied.

R. J. Metzger provided isolates of common bunt that had unique virulence characteristics in initial analyses; 38 originated from the hybrids and 12 were from field collections that originated in Turkey. Twelve of the hybrids and five isolates from field collections that indicated virulence characteristics valuable for elucidating resistance genes in wheat were chosen for further analysis. Six of these were excluded from further tests after showing the same reaction to the differentials as that of known races or other test isolates (Table 3). These common bunt isolates were tested periodically over a 10-year period on all the differentials in fall-planted field nurseries. The isolates selected for analysis were also included in spring-planted field nurseries and in tests conducted in a greenhouse.

Two isolates from field collections of $T$. contraversa that had unique and valuable virulence combinations in initial tests were

Table 2. Named pathogenic races and other isolates of Tilletia contraversa from field collections throughout the northwestern United States that were tested for reaction to wheat lines containing bunt resistance genes Bt11 through Bt15 and Btp

\begin{tabular}{|c|c|c|}
\hline Accession number & Race & Origin \\
\hline 32 & D-1 & Nephi, UT \\
\hline 29 & D-2 & Pullman, WA \\
\hline 379 & D-3 & Kalispell, MT \\
\hline 22 & D-4 & Genesee, ID \\
\hline 36 & D-5 & Mt. Hope, WA \\
\hline 245 & D-6 & Antone, WA \\
\hline 40 & D-7 & Logan, UT \\
\hline 44 & D-8 & Preston, ID \\
\hline 288 & D-9 & Tetonia, ID \\
\hline 108 & D-10 & Blind Spring, UT \\
\hline 260 & D-11 & Hill City, ID \\
\hline 36 & D-12 & Mt. Hope, WA \\
\hline 202 & D-13 & Paris, ID \\
\hline 265 & D-14 & Petersboro, UT \\
\hline 375 & D-15 & Preston, ID \\
\hline 216 & D-16 & Preston, ID \\
\hline 161 & D-17 & Blind Spring, UT \\
\hline 638 & Unknown & San Juan County, UT \\
\hline 688 & Unknown & Hayden, CO \\
\hline 694 & Unknown & Benington, ID \\
\hline 695 & Unknown & Driggs, ID \\
\hline 697 & Unknown & Bozeman, MT \\
\hline 701 & Unknown & Reardon, WA \\
\hline 703 & Unknown & Creston, MT \\
\hline 715 & Unknown & Worley, ID \\
\hline 756 & Unknown & Haines, OR \\
\hline 759 & Unknown & Flora, OR \\
\hline 761 & Unknown & Farmington, WA \\
\hline 770 & Unknown & Paradise, OR \\
\hline
\end{tabular}


evaluated further with the differentials. One isolate originated from Turkey and the other originated from Franklin County, ID and showed virulence to cultivars that were resistant to other known races (20).

The named races and other isolates of common bunt and dwarf bunt fungi were maintained as diseased spikes stored at room temperature. Teliospores in sori maintained under these conditions can retain viability for over 10 years. Pathogenic races that were less than 10 years old were increased on the differentials to validate the correct race reaction. Diseased spikes were collected from the differential that best discriminated the race from others. For example, if only one race is virulent to a specific resistance gene, or if the race is virulent to a gene that rarely confers susceptibility to other races, the bunted spikes were harvested from the differential that carries that gene.

Inoculation-common bunt. Seed for all common bunt tests was inoculated with a concentrated suspension of teliospores in 5\% aqueous methyl cellulose. The methyl cellulose adhered the spores to the seed, which helped avoid cross-contamination of adjacent plots during planting. For small quantities of seed (up to $10 \mathrm{~g}$ ), a few drops of the teliospore suspension was mixed with seed in a glass vial using a vortexer. For larger quantities of seed, the suspension was shaken with seed by hand in an Erlenmeyer flask until the suspension was taken up by the seed, and the seed was evenly and visibly darkened with teliospores.

Field tests-common bunt. Spring-planted and fall-planted field tests with common bunt fungi were performed at the University of Idaho Research and Extension Center in Aberdeen, ID. Fields that had not been planted with wheat for at least 3 years were used to ensure that the soil was free of common bunt teliospores, which lose viability under field conditions within that time period.

Fall-planted common bunt field nurseries were seeded during the second to third week of October, when soil temperatures are typically ideal for infection (approximately 5 to $\left.10^{\circ} \mathrm{C}\right)$. Seed $(5 \mathrm{~g})$ was planted by hand approximately $5 \mathrm{~cm}$ deep into $1.5 \mathrm{-m}$ rows. Each pathogenic race and isolate of common bunt was tested to all the differentials for 2 to 10 seasons. Data on the reaction of differentials Bt11 to Bt15 and Btp to the named races of common bunt were obtained during routine pathogen increases in field nurseries, where the race was inoculated to all the differentials to confirm correct virulence reaction patterns. In tests where infection in the susceptible control line Heines VII had more than $70 \%$ diseased spikes resulting from inoculation with a particular race or isolate, the disease pressure was considered adequate to determine a definitive reaction on the differentials. The virulence reaction of a race or isolate to a particular differential can often be determined even if the positive control has disease levels considerably less than $70 \%$ but avirulent reactions under lower disease pressure are questionable. Data from each season were averaged to determine the avirulent-resistant (0 to $10 \%$ spikes infected) or virulent-susceptible (11 to $100 \%$ spikes infected) reaction of each race or isolatedifferential wheat line interaction in accordance with the methods of Hoffmann and Metzger (25). Data from 2 to 8 seasons were used for the analysis of each named race and isolate.

The spring tetraploid differentials 'Doubbi' (Bt14) and 'Carleton' (Bt15) are not adapted to field conditions during winter, which often resulted in poor or no plant stands in fall-planted nurseries, making it difficult to determine disease reaction. Thus, all named common bunt races and the 17 isolates from R. J. Metzger mentioned above were tested to the Bt14 and Bt 15 differentials and Red Bobs in spring-planted field nurseries using the same methods as described above for the fall-planted nurseries. Tests of each combination of pathogen isolate and wheat differential were conducted in two replicate $1.5-\mathrm{m}$ rows for four consecutive seasons beginning in 2004. Seed for all the spring-planted nurseries was inoculated in the spring of 2004 and separated into subsets for subsequent tests. Inoculated seed was stored at $5^{\circ} \mathrm{C}$ to preserve seed and teliospore viability. The spring nurseries were planted as soon as fields were dry enough to cultivate, which occurred approximately the first week of April, to take advantage of cool soil temperatures that are conducive to disease development. Data from three to four seasons

Table 3. Reaction of isolates of common bunt fungi to wheat differentials with specific bunt resistance genes $(B t)$ that were tested in fall-planted field nurseries $^{\mathrm{a}}$

\begin{tabular}{|c|c|c|c|c|c|c|c|c|c|c|c|c|c|c|c|c|c|c|}
\hline \multirow[b]{2}{*}{ Isolate $^{\mathrm{b}}$} & \multirow[b]{2}{*}{ Years $^{c}$} & \multirow[b]{2}{*}{ Data $^{d}$} & \multicolumn{15}{|c|}{ Diseased spikes (\%) for each bunt resistance gene } & \multirow[b]{2}{*}{ New $^{f}$} \\
\hline & & & Control $^{\mathrm{e}}$ & Bt1 & Bt2 & $B t 3$ & Bt4 & Bt5 & Bt6 & $B t 7$ & Bt8 & Bt9 & Bt10 & Bt11 & Bt12 & Bt13 & Btp & \\
\hline R-36 & 5 & Mean & 83.0 & 0.0 & 76.0 & 0.4 & 3.0 & 0.0 & 3.7 & 66.0 & 45.0 & 0.5 & 0.2 & 0.0 & 0.1 & 84.8 & 0.0 & L-17 \\
\hline T. foetida & & SD & 7.6 & 0.0 & 18.5 & 0.1 & 3.1 & 0.0 & 6.4 & 24.8 & 26.2 & 0.5 & 0.5 & 0.0 & 0.1 & 19.8 & 0.0 & \\
\hline $\mathrm{R}-40$ & 5 & Mean & 93.6 & 70.0 & 79.0 & 38.6 & 7.0 & 71.3 & 1.8 & 60.0 & 0.1 & 2.0 & 0.0 & 0.0 & 0.1 & 1.0 & 40.1 & $\mathrm{~T}-31$ \\
\hline T. caries & & SD & 3.5 & 19.6 & 20.4 & 30.0 & 5.0 & 23.2 & 1.5 & 27.6 & 0.1 & 3.1 & 0.0 & 0.0 & 0.1 & 1.2 & 23.9 & $\ldots$ \\
\hline $\mathrm{R}-43$ & 5 & Mean & 93.7 & 0.0 & 54.0 & 0.1 & 0.8 & 47.5 & 1.3 & 68.0 & 68.3 & 0.2 & 0.5 & 0.0 & 0.0 & 97.2 & 0.1 & L-18 \\
\hline T. foetida & 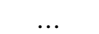 & SD & 4.2 & 0.0 & 32.3 & 0.1 & 0.8 & 13.3 & 1.8 & 19.9 & 16.6 & 0.4 & 0.8 & 0.0 & 0.0 & 2.4 & 0.1 & . \\
\hline R47 & 3 & Mean & 83.3 & 53.3 & 80.0 & 22.3 & 56.7 & 0.0 & 66.7 & 80.0 & 0.3 & 60.0 & 0.0 & 0.0 & 0.0 & 0.0 & 0.0 & T-32 \\
\hline T. caries & $\ldots$ & SD & 7.6 & 10.4 & 5.0 & 9.3 & 15.3 & 0.0 & 5.8 & 5.0 & 0.6 & 8.7 & 0.0 & 0.0 & 0.0 & 0.0 & 0.0 & $\ldots$ \\
\hline $\mathrm{R}-53$ & 6 & Mean & 91.6 & 0.0 & 0.0 & 1.2 & 1.3 & 0.3 & 0.7 & 77.8 & 0.0 & 67.5 & 0.2 & 0.0 & 65.8 & 0.1 & 67.0 & L-19 \\
\hline T. foetida & & SD & 4.9 & 0.0 & 0.0 & 2.9 & 1.0 & 0.8 & 0.5 & 23.9 & 0.0 & 16.0 & 0.4 & 0.0 & 10.7 & 0.1 & 22.2 & $\ldots$ \\
\hline R-54 & 5 & Mean & 92.2 & 63.3 & 79.2 & 0.5 & 83.3 & 72.5 & 84.2 & 64.0 & 0.0 & 73.3 & 67.5 & 0.0 & 0.0 & 0.5 & 0.0 & $\mathrm{~T}-33$ \\
\hline T. caries & $\cdots$ & SD & 7.2 & 16.0 & 13.2 & 0.8 & 8.2 & 13.3 & 6.6 & 24.3 & 0.0 & 16.9 & 13.2 & 0.0 & 0.0 & 0.5 & 0.0 & $\cdots$ \\
\hline R-55 & 8 & Mean & 98.0 & 61.9 & 81.1 & 50.0 & 81.3 & 0.0 & 80.0 & 79.4 & 0.4 & 74.4 & 80.1 & 0.0 & 0.6 & 1.9 & 46.9 & $\mathrm{~T}-34$ \\
\hline T. caries & . & SD & 1.9 & 24.3 & 14.6 & 14.4 & 11.9 & 0.0 & 10.0 & 13.5 & 0.4 & 15.5 & 14.5 & 0.0 & 0.7 & 3.0 & 24.9 & $\ldots$ \\
\hline R-59 & 3 & Mean & 96.3 & 68.3 & 83.3 & 40.0 & 85.0 & 0.0 & 66.7 & 53.3 & 0.2 & 80.0 & 0.0 & 0.0 & 0.1 & 0.0 & 45.0 & T-35 \\
\hline T. caries & & SD & 5.5 & 29.3 & 11.5 & 17.3 & 10.0 & 0.0 & 15.3 & 15.3 & 0.1 & 10.0 & 0.0 & 0.0 & 0.1 & 0.0 & 5.0 & \\
\hline Iso-41 & 3 & Mean & 87.0 & 0.0 & 0.0 & 0.0 & 80.3 & 0.0 & 55.0 & 86.5 & 0.0 & 66.7 & 0.0 & 0.0 & 0.0 & 0.3 & 0.0 & L-20 \\
\hline T. foetida & & SD & 13.9 & 0.0 & 0.0 & 0.0 & 20.6 & 0.0 & 17.3 & 13.9 & 0.0 & 11.5 & 0.0 & 0.0 & 0.0 & 0.6 & 0.0 & \\
\hline Iso-44g & 2 & Mean & 77.5 & 0.0 & 0.0 & 0.0 & 3.0 & 0.0 & 0.1 & 0.0 & 0.0 & 0.0 & 0.0 & 0.0 & 0.0 & 99.5 & 0.0 & T-36 \\
\hline T. caries & & SD & 3.5 & 0.0 & 0.0 & 0.0 & 0.0 & 0.0 & 0.2 & 0.0 & 0.0 & 0.0 & 0.0 & 0.0 & 0.0 & 0.5 & 0.0 & $\ldots$ \\
\hline Iso-51 & 4 & Mean & 85.0 & 50.0 & 0.0 & 0.1 & 3.5 & 0.0 & 0.3 & 47.5 & 5.3 & 47.5 & 0.0 & 0.1 & 0.0 & 0.1 & 0.0 & L-21 \\
\hline T. foetida & $\ldots$ & SD & 7.1 & 14.1 & 0.0 & 0.1 & 4.3 & 0.0 & 0.5 & 29.6 & 2.6 & 22.2 & 0.0 & 0.1 & 0.0 & 0.1 & 0.0 & $\ldots$ \\
\hline
\end{tabular}

${ }^{a}$ Unique virulence combinations were identified and given new pathogenic race designations.

b Isolates of Tilletia foetida or T. caries labeled "R" are selections from hybrids of known races, and those labeled "Iso" are field-collected isolates originating from Turkey (Iso 41 and Iso 44) and the United States (Iso 51).

c Years tested.

${ }^{\mathrm{d}}$ Mean and standard deviation (SD).

${ }^{\mathrm{e}}$ Heines VII, which has no known resistance genes, was used for the positive control

f New race designation.

$\mathrm{g}$ An additional isolate tested for 2 years had the same virulence-avirulence pattern and aggressiveness to $\mathrm{Bt} 13$. 
were used to determine the virulent-susceptible or avirulent-resistant reaction of each race and isolate to the Bt14 and Bt 15 differentials in the spring-planted nurseries.

Greenhouse tests-common bunt. Additional tests were performed to compensate for poor winter survival of the spring wheat by growing inoculated Red Bobs, Bt14, and Bt15 in a greenhouse, where temperatures were adjusted to simulate mild winter condi-

Table 4. Avirulent (A) or virulent (V) reaction of previously named pathogenic races of Tilletia caries ( $\mathrm{T}$ races) and $T$. foetida ( $\mathrm{L}$ races) to wheat differentials containing the resistance genes Bt11, Bt12, Bt13, and $B t p^{\text {a }}$

\begin{tabular}{|c|c|c|c|c|}
\hline \multirow[b]{2}{*}{ Race } & \multicolumn{4}{|c|}{ Bunt resistance gene } \\
\hline & Bt11 & Bt12 & Bt13 & Btp \\
\hline T-1 & A & A & $*$ & A \\
\hline T-2 & A & A & A & A \\
\hline T-3 & A & A & $*$ & A \\
\hline T-4 & A & A & A & A \\
\hline T-5 & A & A & A & A \\
\hline T-6 & A & A & A & A \\
\hline T-7 & A & A & A & A \\
\hline T-8 & A & A & A & A \\
\hline T-9 & A & A & A & A \\
\hline T-10 & A & A & A & A \\
\hline T-11 & A & A & A & A \\
\hline T-12 & A & A & A & A \\
\hline T-13 & A & A & V & A \\
\hline T-14 & A & A & V & A \\
\hline T-15 & A & A & A & A \\
\hline T-16 & A & A & A & A \\
\hline T-17 & A & A & A & A \\
\hline T-18 & A & A & V & A \\
\hline T-19 & A & A & $*$ & V \\
\hline T-20 & A & A & V & A \\
\hline T-21 & A & A & V & A \\
\hline T-22 & A & A & V & A \\
\hline T-23 & A & A & A & A \\
\hline T-25 & A & A & A & A \\
\hline T-26 & A & A & A & A \\
\hline T-27 & A & A & $*$ & A \\
\hline T-28 & A & A & A & A \\
\hline T-29 & A & A & $*$ & A \\
\hline T-30 & A & A & A & A \\
\hline L-1 & A & A & A & A \\
\hline L-2 & A & A & A & A \\
\hline L-3 & A & A & A & A \\
\hline L-4 & A & A & A & A \\
\hline L-5 & A & A & A & A \\
\hline L-7 & A & A & $*$ & A \\
\hline L-8 & A & A & A & A \\
\hline L-9 & A & A & A & A \\
\hline L-10 & A & A & V & V \\
\hline L-16 & A & A & A & A \\
\hline
\end{tabular}

${ }^{a}$ Reaction based on a minimum of two experiments in field nurseries during separate seasons. $\mathrm{A}=0-10 \%$ infected spikes and $\mathrm{V}=11-100 \%$. Race T-24 was lost and, thus, is not included; an asterisk (*) indicates that Bt13 was not included in sufficient tests to determine reaction. tions. A subset of the inoculated seed prepared for the springplanted field nurseries was used for the greenhouse tests. Inoculated seed of each differential was sown approximately $4 \mathrm{~cm}$ deep into two $15-\mathrm{cm}$-diameter plastic pots that were maintained in a greenhouse at approximately 5 to $10^{\circ} \mathrm{C}$ for a minimum of 8 weeks during the winter. The greenhouse was gradually warmed during early spring to approximately $30^{\circ} \mathrm{C}$ during the day and $18^{\circ} \mathrm{C}$ during the night. Plants were grown to maturity and the percent diseased spikes in each of the two pots was averaged. The experiment was repeated in each of three separate seasons.

Greenhouse tests-dwarf bunt. An artificial inoculation procedure was used for $T$. contraversa tests in the greenhouse (17) to avoid complications encountered in field tests. Inoculation in typical dwarf bunt field-screening nurseries is done by spraying a water suspension of teliospores onto the soil surface after planting. Using these methods to test different races of $T$. contraversa in the field is not possible due to potential cross contamination from adjacent soil-inoculated plots. There could also be residual inoculum in soils contaminated with long-lived teliospores in disease-conducive areas. Moreover, inoculating seed with $T$. contraversa teliospores prior to planting (as is done to induce common bunt) has very little or no effect on the induction of dwarf bunt (22). The artificial inoculation procedure that was used to induce dwarf bunt involved placing approximately $3 \mathrm{~g}$ of seed of each differential into a $9-\mathrm{cm}$ petri dish containing teliospores germinating on agar, followed by adding approximately $3 \mathrm{ml}$ of water and then mixing with a clean finger until seed was uniformly wet with a suspension of germination products consisting of fused primary sporidia, secondary sporidia, and hyphae. Inoculated seed was sown $5 \mathrm{~cm}$ deep into moist vermiculite in an 11-cm-diameter plastic pot which was then covered with foil. Pots were incubated at $10^{\circ} \mathrm{C}$ for approximately 2 weeks; then, about 12 seedlings were transplanted into soil in each of two 15-cm-diameter pots (17). Plants were maintained in the greenhouse at 5 to $10^{\circ} \mathrm{C}$ during winter for a minimum of 8 weeks. The cool greenhouse temperatures simulated mild winter conditions and vernalized the winter wheat. The greenhouse was gradually warmed to $30^{\circ} \mathrm{C}$ during the day and $18^{\circ} \mathrm{C}$ during the night during early spring. Plants were grown to maturity, after which the percent diseased spikes in each of the two pots was averaged.

The artificial inoculation method was used to test the reaction of the susceptible control Red Bobs and the Bt11 to Bt15 differentials to all the named pathogenic races of $T$. contraversa (D-1 to D-17). In addition, 11 isolates of $T$. contraversa from field collections that originated from the widest possible geographic area in the northwestern United States (Table 2) were included in the same tests to examine the potential virulence of additional isolates to the newer differentials. Tests were conducted over five winter seasons. Data from a minimum of three seasons where infection in Red Bobs was $70 \%$ or higher were averaged to determine the avirulent or virulent reaction of the races and isolates to Bt11 to Bt15. Infection of the Btp differential induced by the named races was recorded after artificial inoculation in a minimum of two tests performed during race increases with the differentials, as described for the common bunt race increases.

Table 5. Reaction of isolates of Tilletia contraversa to wheat differentials with specific bunt resistance genes (Bt) after artificial inoculation and growth in a greenhouse adjusted to simulate mild winter conditions ${ }^{\text {a }}$

\begin{tabular}{|c|c|c|c|c|c|c|c|c|c|c|c|c|c|c|c|c|c|c|}
\hline \multirow[b]{2}{*}{ Isolate $^{\mathbf{b}}$} & \multirow[b]{2}{*}{ Years $^{c}$} & \multirow[b]{2}{*}{ Data $^{d}$} & \multicolumn{15}{|c|}{ Diseased spikes (\%) for each bunt resistance gene } & \multirow[b]{2}{*}{$\mathrm{New}^{\mathrm{f}}$} \\
\hline & & & Control $^{\mathrm{e}}$ & Bt1 & Bt2 & Bt3 & Bt4 & Bt5 & Bt6 & $B t 7$ & Bt8 & Bt9 & Bt10 & Bt11 & Bt12 & Bt13 & Btp & \\
\hline \multirow[t]{2}{*}{ Prom } & 5 & Mea & 64.2 & 54.2 & 91.7 & 30.7 & 37.8 & 0.5 & 77.5 & 41.7 & 16.2 & 63.0 & 68.3 & 1.7 & 1.5 & 21.8 & 62.5 & D-18 \\
\hline & & SD & 15.0 & 20.8 & 8.1 & 13.7 & 21.4 & 1.2 & 14.7 & 25.7 & 11.9 & 19.1 & 23.8 & 1.9 & 1.5 & 20.4 & 19.9 & \\
\hline \multirow[t]{2}{*}{ TR29-1 } & 4 & Mean & 48.3 & 0.0 & 76.8 & 42.5 & 65.0 & 23.3 & 86.3 & 51.7 & 85.0 & 38.3 & 73.8 & 38.3 & 66.3 & 85.5 & 48.3 & D-19 \\
\hline & $\ldots$ & SD & 12.6 & 0.0 & 25.5 & 15.0 & 12.9 & 11.0 & 4.8 & 14.4 & 5.8 & 17.3 & 6.3 & 2.9 & 11.8 & 9.9 & 36.2 & \\
\hline
\end{tabular}

\footnotetext{
${ }^{a}$ Unique virulence combinations were identified and given new race designations.

${ }^{\mathrm{b}}$ Isolates originated from field collections in Idaho (Prom) and Turkey (TR29-1).

c Years tested.

${ }^{\mathrm{d}}$ Mean and standard deviation (SD).

${ }^{\mathrm{e}}$ Heines VII, which has no known resistance genes and is poorly adapted to greenhouse conditions, was used for the positive control.

${ }^{\mathrm{f}}$ New race designation.
} 
In initial tests, two isolates of dwarf bunt from field collections indicated unique patterns of virulence to the differentials. These isolates were analyzed further on all of the differentials in tests over a period of 4 to 5 years. Infection data from each test were averaged to determine the virulent or avirulent reaction of the isolates to the differentials.

Uninoculated seed of each wheat line tested was included in all field and greenhouse tests to ensure that any bunt produced was a result of the inoculation. In all tests, a reaction was considered avirulent when $10 \%$ or less of the spikes were diseased, and virulent if the disease exceeded $10 \%$ (25).

\section{Results and Discussion}

Reaction of Bt14 and Bt15 to common bunt isolates. Comparison of the results of common bunt tests of the spring tetraploid differentials Doubbi (Bt14) and Carleton (Bt15) with the named races and the additional isolates in fall-planted and spring-planted field tests and greenhouse tests demonstrated that the environment often influenced bunt incidence in these differentials. The same overall level of disease pressure occurred in spring and winter tests, where the mean bunt infection in the Red Bobs and Heines VII positive control lines inoculated with all isolates averaged 60.0 and $60.2 \%$ bunted spikes, respectively. However, of the 51 isolates tested, 24 isolates which were avirulent to either $B t 14$ or $B t 15$ or both $B t 14$ and $B t 15$ in the spring field tests were virulent to the differentials when tested under simulated winter conditions in the greenhouse and in fall-planted field tests. One isolate had virulence to Bt15 in spring-planted nurseries but was avirulent in the simulated winter conditions. The remaining 26 isolates had the same avirulent or virulent rating in spring and greenhouse winter tests. For 15 of the 51 isolates tested in the fall-planted field nurseries, there was insufficient data to determine the virulent or avirulent reaction of the isolates to $B t 14$ and $B t 15$ due to poor plant stands in these spring wheat lines. In tests with the remaining 36 isolates that had adequate plant stands in fall-planted nurseries, the virulent or avirulent reactions to $\mathrm{Bt} 14$ and $\mathrm{Bt} 15$ always matched those from the simulated winter conditions in the greenhouse. This indicates the resistance genes in Doubbi (Bt14) and Carleton (Bt15) have sensitivity to temperature or other environmental factors that renders them less effective under winter conditions with specific bunt races or isolates.

Environmental influences on the effectiveness of bunt resistance has been reported previously, where it was shown that resistance in certain wheat lines is less effective when plants are grown in extensive cool conditions $(15,23,37,43)$. Similarly, in recent race tests conducted by Matanguihan and Jones (32) with common bunt isolates in fall- and spring-planted nurseries, there was too much variability from year to year to accurately determine the reaction of the isolates to Bt14 and Bt15.

The initial tests with common bunt conducted by R. J. Metzger in relatively mild winter field environments near Corvallis, OR showed that only race L-7 was virulent to $B t 14$ and only races T-2 and L-2 were virulent to Bt15 (17). In the current tests, conducted in the colder winter environments of southeastern Idaho, 16 of the 51 isolates tested had virulence to Bt14 and 48 isolates had virulence to Bt15. Environmental variation might account for this difference. Although the resistance factors in Doubbi (Bt14) and Carleton (Bt15) may indeed represent valid resistance genes, the reaction seems too variable in different environments to accurately assess virulence or avirulence. It is not known if the Bt14 gene named in 'Eryth-5221' by Liatukas and Ruzgas, (30) is the same as the Bt14 gene of Doubbi used here. Pathogenic race tests with Doubbi and Carleton that may be conducted in the different areas of the world, and variable environments within them, can make race determination with these two differentials unreliable. In addition, utilizing these spring wheat lines makes comparison with the remainder of the differentials in the same field experiments problematic, because the rest are winter wheat lines. Thus, although the Bt14 and Bt15 differentials were included in all tests conducted here with common bunt and dwarf bunt fungi, the specific ratings of these differentials to the races are not presented to avoid giving potentially misleading information. Further, it is proposed that Doubbi and Carleton be dropped from the set of bunt differentials.

Common bunt field screening of new isolates. Testing the 17 hybrids and isolates of common bunt fungi provided by R. J. Metzger to all the differential wheat lines under high disease pressure in fall-planted field nurseries demonstrated that 11 of them had unique patterns of virulence to the differentials. Six new pathogenic races of $T$. caries and five new races of $T$. foetida were identified. These isolates were given new race designations that expanded the list of named pathogenic races (Table 3 ). The remaining six isolates had the same virulence pattern as known races or other test isolates after 2 to 3 years of tests, and were excluded from further analysis. The new races will assist the elucidation of resistance genes by examining the reaction of resistant wheat to several races.

None of the previously named races of common bunt fungi were virulent to $B t 8, B t 11$, or $B t 12(17,25,34)$. However, in the current tests, two of the new races, L-17 and L-18, had virulence to Bt8 and one, L-19, had virulence to Bt12. Bt11 remained uncompromised by any of the new common bunt races identified in this study. Bt8 and Bt12 are the primary genes responsible for resistance to bunt among cultivars that are commonly grown in the Pacific Northwestern United States Bt8 originated from PI 178383 and $B t 12$ originated from CI $14106(16,21)$. The new races virulent to $B t 8$ and $B t 12$ will enable specific targeting of these resistance genes in wheat screening tests.

The new race T-34 had virulence to nine of the differentials (Table 3). This represents the highest number of genes compromised by any common bunt race reported. Race T-34 had the same pattern of virulence and avirulence to the resistance genes $B t 1$ through $B t 13$ as that described recently for an isolate of T. caries identified in the northwestern United States (32). Similar to T-34, this isolate also showed virulence to Btp based on limited tests (Matanguihan, personal communication), indicating that the isolate is the same race as race T-34 described here. Race T-35 had virulence to one fewer gene (Bt10) than T-34. Screening wheat lines with these two races would indicate the presence of Bt10, if the wheat is susceptible to T-34 but resistant to T-35.

Race T-36 had virulence to only one differential, Bt13. An additional isolate, Iso47 (data not shown), was tested for 2 years during these experiments and had the same pattern of aggressive virulence, with an average of $77.5 \%$ bunted spikes in the susceptible Heines VII, $97.5 \%$ in Bt13, and 0 to $1.6 \%$ in the other differentials. Of the common bunt disease reactions between individual racedifferential combinations that occurred in tests with the 11 new common bunt races identified, the virulent or avirulent reaction to the $B t 13$ differential was more extreme than the reaction in the other differentials (Table 3). Depending on the race of the inoculum, Bt13 was either highly effective, causing complete or nearly complete disease resistance, or ineffective, which resulted in $100 \%$ diseased spikes in many individual tests. The average mean bunt infection of $B t 13$ produced by the virulent races was $93.8 \%$, whereas the avirulent races produced an average mean infection of $0.5 \%$. In the same tests, Heines VII averaged 84.7 and $90.8 \%$ diseased spikes when inoculated with races having virulence and avirulence, respectively, to $B t 13$, demonstrating a near equal level of disease pressure. The level of the virulence of the other races to individual $B t$ genes other than $B t 13$ was less severe and had an average bunt infection that ranged between 36.3 and $75.9 \%$ diseased spikes. The extremely divergent reaction of these new races to Bt13 indicates that the interaction would be a good candidate for studies of the microbiology or molecular biology of resistance gene expression and function in host-pathogen interactions. The best race for such studies might be T-36, given that the race has virulence only to $B t 13$, eliminating the potential influence of other virulence factors. This could be compared with the reaction with races such as T-1, T-14, or L- 1 that are avirulent to Bt13 and virulent to only one of the other $B t$ genes. 
In the tests conducted here, the universally susceptible Heines VII had a relatively consistent high level of infection in tests over several years whereas, in the same tests, some race-differential interactions had considerable year-to-year variation in disease severity, as indicated by a high standard deviation (SD) relative to the mean percent infected spikes (Table 3). This suggests that certain race-host combinations are more susceptible to environmental influences than other combinations, which had a low SD.

Reaction of previously named races of common bunt fungi to $B t 11, B t 12, B t 13$, and Btp. The reaction of the named races of common bunt fungi to $B t 11, B t 12, B t 13$, and $B t p$ that was recorded

Table 6. Virulence formula summary of the reaction of 14 wheat lines with specific bunt resistance genes $(B t)$ to pathogenic races of Tilletia caries ("T" races), T. foetida (" $\mathrm{L}$ " races), and T. contraversa ("D" races)

\begin{tabular}{|c|c|}
\hline Race & Virulence or avirulence to $B t$ genes $^{\mathrm{a}}$ \\
\hline $\mathrm{T}-10$ & $5 / 1,2,3,4,6,7,8,9,10,11,12,13, \mathrm{p}$ \\
\hline L-1 & $7 / 1,2,3,4,5,6,8,9,10,11,12,13, \mathrm{p}$ \\
\hline $\mathrm{T}-1$ & $7 / 1,2,3,4,5,6,8,9,10,11,12,13^{*}, \mathrm{p}$ \\
\hline $\mathrm{T}-36$ & $13 / 1,2,3,4,5,6,7,8,9,10,11,12, \mathrm{p}$ \\
\hline T-2, L-4 & $1,7 / 2,3,4,5,6,8,9,10,11,12,13, \mathrm{p}$ \\
\hline $\mathrm{T}-14$ & $1,13 / 2,3,4,5,6,7,8,9,10,11,12, \mathrm{p}$ \\
\hline T-11 & $2,3 / 1,4,5,6,7,8,9,10,11,12,13, \mathrm{p}$ \\
\hline L-3 & $2,7 / 1,3,4,5,6,8,9,10,11,12,13, p$ \\
\hline $\mathrm{T}-3$ & $2,7 / 1,3,4,5,6,8,9,10,11,12,13^{*}, \mathrm{p}$ \\
\hline T-9 & $5,7 / 1,2,3,4,6,8,9,10,11,12,13, \mathrm{p}$ \\
\hline D-1 & $7,10 / 1,2,3,4,5,6,8,9,11,12,13, p$ \\
\hline L-9 & $1,2,3 / 4,5,6,7,8,9,10,11,12,13, \mathrm{p}$ \\
\hline T-5, L-5, D-4 & $1,2,7 / 3,4,5,6,8,9,10,11,12,13, \mathrm{p}$ \\
\hline $\mathrm{T}-20$ & $1,2,13 / 3,4,5,6,7,8,9,10,11,12, \mathrm{p}$ \\
\hline $\mathrm{T}-12$ & $1,5,7 / 2,3,4,6,8,9,10,11,12,13, p$ \\
\hline L-21 & $1,7,9 / 2,3,4,5,6,8,10,11,12,13, \mathrm{p}$ \\
\hline $\mathrm{T}-25$ & $1,7,10 / 2,3,4,5,6,8,9,11,12,13, \mathrm{p}$ \\
\hline T-17, D-2 & $4,6,7 / 1,2,3,5,8,9,10,11,12,13, p$ \\
\hline $\mathrm{T}-13$ & $1,2,3,13 / 4,5,6,7,8,9,10,11,12, \mathrm{p}$ \\
\hline $\mathrm{T}-15$ & $1,2,5,7 / 3,4,6,8,9,10,11,12,13, \mathrm{p}$ \\
\hline T-26 & $1,2,7,10 / 3,4,5,6,8,9,11,12,13, \mathrm{p}$ \\
\hline L-10 & $2,3,7,13, \mathrm{p} / 1,4,5,6,8,9,10,11,12$ \\
\hline D-10 & $2,3,7, \mathrm{p} / 1,4,5,6,8,9,10,11,12,13$ \\
\hline L-17 & $2,7,8,13 / 1,3,4,5,6,9,10,11,12, \mathrm{p}$ \\
\hline L-20 & $4,6,7,9 / 1,2,3,5,8,10,11,12,13, \mathrm{p}$ \\
\hline D-11 & $4,6,7,10 / 1,2,3,5,8,9,11,12,13, \mathrm{p}$ \\
\hline L-19 & $7,9,12, \mathrm{p} / 1,2,3,4,5,6,8,10,11,13$ \\
\hline T-19 & $1,2,3,7, \mathrm{p} / 4,5,6,8,9,10,11,12,13 *$ \\
\hline D-8 & $1,2,3,7, \mathrm{p} / 4,5,6,8,9,10,11,12,13$ \\
\hline L-16, D-6 & $1,2,4,6,7 / 3,5,8,9,10,11,12,13, \mathrm{p}$ \\
\hline $\mathrm{T}-29$ & $1,2,7,9,10 / 3,4,5,6,8,11,12,13^{*}, \mathrm{p}$ \\
\hline D-5 & $1,4,6,7 / 2,3,5,8,9,10,11,12,13, \mathrm{p}$ \\
\hline D-12 & $1,4,6,7,10 / 2,3,5,8,9,11,12,13, \mathrm{p}$ \\
\hline $\mathrm{T}-18$ & $1,4,6,7,13 / 2,3,5,8,9,10,11,12, \mathrm{p}$ \\
\hline T-16 & $2,4,5,6,7 / 1,3,8,9,10,11,12,13, \mathrm{p}$ \\
\hline T-28, L-8 & $2,4,6,7,9 / 1,3,5,8,10,11,12,13, \mathrm{p}$ \\
\hline $\mathrm{T}-22$ & $2,4,6,7,13 / 1,3,5,8,9,10,11,12, p$ \\
\hline L-18 & $2,5,7,8,13 / 1,3,4,6,9,10,11,12, \mathrm{p}$ \\
\hline $\mathrm{T}-21$ & $1,2,4,6,7,13 / 3,5,8,9,10,11,12, p$ \\
\hline $\mathrm{T}-31$ & $1,2,3,5,7, \mathrm{p} / 4,6,8,9,10,11,12,13$ \\
\hline $\mathrm{T}-23$ & $1,2,4,6,7,9 / 3,4,8,10,11,12,13, \mathrm{p}$ \\
\hline $\mathrm{T}-27$ & $1,2,4,6,7,10 / 3,5,8,9,11,12,13^{*}, \mathrm{p}$ \\
\hline D-14 & $2,3,4,6,7,10, \mathrm{p} / 1,5,8,9,11,12,13$ \\
\hline D-17 & $2,3,7,9,13, \mathrm{p} / 1,4,5,6,8,10,11,12$ \\
\hline T-32 & $1,2,3,4,6,7,9 / 5,8,10,11,12,13, \mathrm{p}$ \\
\hline D-3 & $1,2,3,4,6,7, \mathrm{p} / 5,8,9,10,11,12,13$ \\
\hline D-16 & $1,2,3,7,9,13, \mathrm{p} / 4,5,6,8,10,11,12$ \\
\hline $\mathrm{T}-30$ & $1,2,4,6,7,9,10 / 3,5,8,11,12,13, \mathrm{p}$ \\
\hline $\mathrm{T}-33$ & $1,2,4,5,6,7,9,10 / 3,8,11,12,13, \mathrm{p}$ \\
\hline D-13 & $1,2,4,6,7,10,13 / 3,5,8,9,11,12, \mathrm{p}$ \\
\hline $\mathrm{T}-35$ & $1,2,3,4,6,7,9, \mathrm{p} / 5,8,10,11,12,13$ \\
\hline $\mathrm{T}-34$ & $1,2,3,4,6,7,9,10, \mathrm{p} / 5,8,11,12,13$ \\
\hline D-15 & $1,2,3,4,6,7,10,13, \mathrm{p} / 5,8,9,11,12$ \\
\hline D- $7^{b}$ & $2,3,4,6,7,11,12,13, \mathrm{p} / 1,5,8,9,10$ \\
\hline D-18 & $1,2,3,4,6,7,8,9,10,13, \mathrm{p} / 5,11,12$ \\
\hline D-19 & $2,3,4,5,6,7,8,9,10,11,12,13, \mathrm{p} / 1$ \\
\hline
\end{tabular}

a An asterisk $(*)$ indicates that the avirulent reaction of Bt13 needs confirmation.

b Virulent reaction to Bt11 and Bt12 with race D-7 was slight. in a minimum of 2 years of fall-planted field tests during pathogen increases are presented as avirulent or virulent in Table 4 . Like the preliminary tests (17), no previously named race of common bunt was virulent to Bt11 or Bt12 in the current experiments. However, in the previous tests, only a single common bunt race, T-13, was virulent to $B t 13$ whereas, in the current experiments, virulence to Bt13 was detected in T-13, T-14, T-18, T-20, T-21, T-22, and L-10. Thus, the reaction of the previously named races of common bunt fungi to Bt13 has been updated (Table 4). Data that lead to conclusions of the avirulence or virulent reaction of $B t 13$ in the previous report (17) have not been presented and were based on a personal communication (R. J. Metzger). Thus, the reason for the discrepancy in the current and previous report can only be speculative. However, the current experiments describe disease reactions of $B t 13$ to the races in repeated experiments under high disease pressure, which should be conclusive.

The reaction of the previously named common bunt races to Btp was identified for the first time and showed that only two races, T19 and L-10, had virulence to Btp (Table 4). Of the new common bunt races, 4 of the 11 had virulence to Btp. Other common bunt isolates tested to Btp outside the United States have not detected virulence to this differential $(26,42)$. Similarly, virulence to $B t 11$ and $B t 12$ has not been detected in common bunt isolates that have been tested to these differentials in various regions of the world $(1,4,9,12,26,28,30,31,42)$, indicating the potential broad applicability of these genes in resistance breeding. The resistance gene Bt11 in the wheat PI 166910 that was used to develop the Bt11 differential continues to be the most difficult bunt resistance gene to overcome. The resistance from PI 166910 has not been utilized for dwarf bunt or common bunt resistance in cultivar development even though it appears to have considerable value for such purpose. Only a single race of common bunt (new race L-19) had virulence to $B t 12$, and it was developed through artificial hybridization. Bt12 has been highly effective for control of dwarf bunt in winter wheat cultivars in the United States that are grown in areas that are prone to the disease. Bt12 was introgressed from either CI 14106 or PI 476214 that have been demonstrated to carry the gene (B. J. Goates, unpublished).

In the last update of pathogenic races of common bunt in 1976 (25), some races were designated as different races, even though they had the same pattern of virulence to the 10 differentials containing Btl to Bt10, indicating that they may be the same pathogenic race. These duplicate races can be separated into four groups with identical virulence-avirulence patterns: (i) T-2, T-4, and T-6; (ii) T-5, T-7, and T-8; (iii) L-1 and L-2; and (iv) L-5, L-6, and L-7. In the current study, testing these races with the four additional differentials containing the $B t 11, B t 12, B t 13$, and Btp genes also did not differentiate the races within the groups from each other, as is shown in a summary of the reaction of the differentials to all the races in Table 6. Thus, it seems appropriate to retain the race designations T-2, T-5, L-1, and L-5 and drop their duplicates (T-4 and T6 , T-7 and T-8, and L-2, respectively) from the list of common bunt races unless new differentials can be identified to differentiate these isolates from each other. Reactions for L- 6 are not included in the results here because race L-6 was dropped as a duplicate race prior to these experiments. The reaction of $\mathrm{L}-7$ to $B t 13$ was inconclusive; thus, it should be retained and considered a duplicate to L-5 until the reaction to this gene can be determined.

Race identification of new $T$. contraversa isolates. The two $T$. contraversa isolates that were tested with the differentials showed unique virulence-avirulence patterns and were given the new race designations D-18 and D-19 (Table 5). D-18 had virulence to the combination of $B t 9$ and $B t 10$, which is the first documentation of this virulence combination in a race of $T$. contraversa. The virulence of D-18 to $B t 9$ and $B t 10$ in addition to virulence to $B t 3$ appears to be responsible for overcoming the dwarf bunt resistance reported previously (19) in cultivars such as 'Hansel', 'Manning', 'Promontory', and 'Utah 100' that had been highly resistant since the form of resistance in these wheat lines was first released in cultivars during the mid-1970s and early 1980s $(10,11)$. The weak 
virulent reaction of D-18 to Bt8 varied considerably in different tests, as indicated by the high SD in infection rates. The virulence of D-18 to Bt 8 does not appear to be important in the susceptibility of the previously resistant cultivars to D-18 because the new common bunt race T-34 produced a high level of disease in these cultivars but lacks virulence to $B t 8$ (20). Testing breeding lines with race T-34 has been valuable for eliminating susceptibility to D-18 (B. J. Goates and D. Hole, unpublished).

The new race D-19 was virulent to all the $B t$ genes, with the exception of Btl. This is by far the highest level of virulence recorded for any race of $T$. contraversa, $T$. caries, or $T$. foetida. D-19 also produced high levels of disease on the differentials that carry the genes $B t 8, B t 11$, and $B t 12$ that are either rarely compromised (Bt8 and Bt12) or not compromised (Bt11) by common bunt races (Table 5). This is the first time any race of common bunt or dwarf bunt has shown significant virulence to Bt11, which had an average infection rate of about $40 \%$ after inoculation with D-19. The landrace wheat PI 178383 has the resistance genes Bt8, Bt9, and Bt10 and unidentified factors (24). PI 178383 is commonly included in all common bunt and dwarf bunt race evaluations and screening nurseries conducted by the author and in previous tests conducted by Hoffmann and Metzger and has been extremely resistant or immune to all bunt races and isolates in numerous tests (B. J. Goates, unpublished). However, PI 178383 was included in the current race evaluations and was usually susceptible to race D-19. In one test, PI 178383 had 40\% infected spikes (data not shown). This is the first time that this wheat has shown susceptibility to common bunt or dwarf bunt fungi. The new races of $T$. controversa have been valuable for use in disease screening tests to elucidate the genes of resistant wheat and to discover new sources of resistance (B. J. Goates, unpublished). The Heines VII positive control in the dwarf bunt greenhouse tests had a relatively low mean infec- tion of about 50 to $60 \%$. However, the high levels of infection among other differentials in the tests indicated that the moderate disease reaction of Heines VII may be due to poor agronomic performance under the greenhouse conditions, previously noted, rather than disease escape. Numerous additional dwarf bunt isolates have been taken through preliminary pathogenic race analyses and have indicated new virulence combinations (B. J. Goates, unpublished), suggesting that there is still considerable diversity of virulence among $T$. controversa collections yet to be described.

Reaction of named races and isolates of $T$. contraversa to Bt11, Bt12, Bt13, and Btp. A high level of disease pressure occurred in greenhouse tests when the previously named $T$. contraversa races and the additional isolates were tested to the newer differentials, which clearly defined their virulent or avirulent reactions to the newer differentials (Table 7). Bt11 and Bt12 were resistant to all of the previously named races and isolates of $T$. contraversa except race D-7, which induced a weak virulent reaction with a mean of 14.5 and $13.0 \%$ infected spikes, respectively. This is compared with the reaction of $B t 11$ and $B t 12$ to the new race D19 , which had a fairly strong virulent reaction to Bt11 (mean $38.3 \%$ ) and $B t 12$ (mean $66.3 \%$ ). The average bunt infection produced by D-7 to Bt11 and Bt12 just exceeded the defined infection level of $10 \%$ for a virulence rating. A considerable amount of variation occurred in the disease reaction of Bt11 when inoculated with D-7 in the five experiments performed with this race, as is reflected in the high SD. Some reactions of Bt11 in tests with D-7 were well above that required for a virulence rating. In two tests, infection exceeded $30 \%$ but, in two other tests, the infection was 0 and $2 \%$, which indicated avirulence. Repeated testing was required to elucidate the virulent reaction even though all the tests had 80 to $100 \%$ infection in the Red Bobs positive control. As mentioned by Matanguihan et al. (33), year-to-year variation in reaction to resis-

Table 7. Disease reaction of pathogenic races (D) and numbered isolates of Tilletia contraversa to wheat differentials with specific resistance bunt genes (Bt) after artificial inoculation

\begin{tabular}{|c|c|c|c|c|c|c|c|c|c|}
\hline \multirow[b]{3}{*}{ Race, isolate } & \multicolumn{8}{|c|}{ Diseased spikes (\%) for each bunt resistance gene ${ }^{a}$} & \multirow[b]{3}{*}{$B t p^{c}$} \\
\hline & \multicolumn{2}{|c|}{ Control $^{b}$} & \multicolumn{2}{|c|}{ Bt11 } & \multicolumn{2}{|c|}{ Bt12 } & \multicolumn{2}{|c|}{ Bt13 } & \\
\hline & Mean & SD & Mean & SD & Mean & SD & Mean & SD & \\
\hline D-1 & 89.4 & 11.1 & 0.0 & 0.0 & 0.0 & 0.0 & 2.5 & 3.8 & A \\
\hline D-2 & 97.8 & 1.9 & 0.0 & 0.0 & 0.0 & 0.0 & 2.5 & 1.9 & A \\
\hline D-3 & 93.6 & 7.9 & 0.0 & 0.0 & 0.0 & 0.0 & 1.0 & 1.2 & $\mathrm{~V}$ \\
\hline D-4 & 85.0 & 11.7 & 0.0 & 0.0 & 0.0 & 0.0 & 3.0 & 3.8 & A \\
\hline D-5 & 89.8 & 10.5 & 0.0 & 0.0 & 0.0 & 0.0 & 2.3 & 3.3 & A \\
\hline D-6 & 86.3 & 7.5 & 0.0 & 0.0 & 0.0 & 0.0 & 2.0 & 3.5 & A \\
\hline D-7 & 86.7 & 8.2 & 14.5 & 14.7 & 13.0 & 2.6 & 27.8 & 24.5 & V \\
\hline D-8 & 96.3 & 4.2 & 1.0 & 1.7 & 0.0 & 0.0 & 2.3 & 2.5 & V \\
\hline D-9 & 91.3 & 7.5 & 0.0 & 0.0 & 0.0 & 0.0 & 0.8 & 1.5 & V \\
\hline D-10 & 86.3 & 15.1 & 0.5 & 1.0 & 0.0 & 0.0 & 0.5 & 1.0 & $\mathrm{~V}$ \\
\hline D-11 & 78.8 & 8.5 & 0.0 & 0.0 & 0.0 & 0.0 & 4.3 & 2.6 & A \\
\hline D-12 & 92.3 & 8.4 & 0.0 & 0.0 & 0.0 & 0.0 & 3.8 & 5.7 & A \\
\hline D-13 & 90.0 & 7.1 & 0.0 & 0.0 & 0.0 & 0.0 & 39.0 & 29.7 & A \\
\hline D-14 & 91.0 & 10.8 & 0.0 & 0.0 & 0.3 & 0.5 & 1.3 & 1.5 & $\mathrm{~V}$ \\
\hline D-15 & 81.3 & 8.5 & 0.0 & 0.0 & 0.0 & 0.0 & 31.0 & 24.3 & $\mathrm{~V}$ \\
\hline D-16 & 80.0 & 14.7 & 0.0 & 0.0 & 0.0 & 0.0 & 36.2 & 27.7 & $\mathrm{~V}$ \\
\hline D-17 & 78.8 & 12.5 & 0.0 & 0.0 & 0.3 & 0.5 & 37.3 & 21.6 & $\mathrm{~V}$ \\
\hline 638 & 96.0 & 1.7 & 0.0 & 0.0 & 0.0 & 0.0 & 15.3 & 3.1 & $\ldots$ \\
\hline 688 & 82.5 & 11.9 & 0.0 & 0.0 & 0.0 & 0.0 & 0.3 & 0.6 & $\ldots$ \\
\hline 694 & 93.8 & 8.0 & 0.0 & 0.0 & 0.3 & 0.6 & 17.0 & 8.7 & $\ldots$ \\
\hline 695 & 96.2 & 1.6 & 0.0 & 0.0 & 0.0 & 0.0 & 0.0 & 0.0 & $\ldots$ \\
\hline 697 & 95.8 & 1.5 & 0.0 & 0.0 & 0.0 & 0.0 & 4.0 & 4.0 & $\ldots$ \\
\hline 701 & 88.8 & 9.4 & 0.0 & 0.0 & 0.4 & 0.5 & 20.0 & 7.6 & $\ldots$ \\
\hline 703 & 92.2 & 9.7 & 0.0 & 0.0 & 1.0 & 1.7 & 0.3 & 0.6 & $\ldots$ \\
\hline 715 & 96.4 & 1.3 & 0.0 & 0.0 & 0.0 & 0.0 & 26.0 & 12.7 & $\ldots$ \\
\hline 756 & 97.0 & 4.0 & 0.0 & 0.0 & 0.0 & 0.0 & 14.3 & 4.0 & $\ldots$ \\
\hline 759 & 90.8 & 7.9 & 0.0 & 0.0 & 0.0 & 0.0 & 30.3 & 25.9 & $\ldots$ \\
\hline 761 & 93.5 & 4.4 & 0.0 & 0.0 & 0.0 & 0.0 & 3.0 & 5.2 & $\ldots$ \\
\hline 770 & 85.0 & 20.4 & 0.0 & 0.0 & 0.7 & 1.2 & 25.7 & 8.1 & $\ldots$ \\
\hline
\end{tabular}

${ }^{\mathrm{a}}$ Mean $=$ mean percent infected spikes in a minimum of three seasonal experiments and $\mathrm{SD}=$ standard deviation.

${ }^{\mathrm{b}}$ Red Bobs, which has no known resistance genes, was used as the positive control.

${ }^{c}$ Avirulent (A) and virulent (V) reaction to Btp was determined during race increases in a minimum of two separate tests; 0-10\% infected spikes $=$ A and $11-100 \%=\mathrm{V}$. The reaction to Btp was not determined for the numbered isolates. 
tance genes can occur, requiring repeated testing with high disease pressure before a definitive reaction to the differentials can be determined. Year-to-year variation of the reactions of differentials in race tests has also been observed by Hoffmann (24).

About half of the T. contraversa races and isolates had virulence to $B t 13$ (Table 7). The extreme disease reaction of $B t 13$ that occurred in interactions with the new common bunt races virulent to $B t 13$ described above was not apparent in the tests with dwarf bunt races. Although the reaction of Bt14 and Bt15 is not listed in the table for reasons given above, all races and isolates were virulent to Bt14 except D-4, D-8, and D-10; and all were virulent to Bt15 except D-4 and isolate number 688 . The dwarf bunt tests were conducted only in simulated mild winter conditions in the greenhouse; therefore, it is not known whether post-infection temperature influences dwarf bunt infection in Bt14 and Bt15 as was shown in the tests with common bunt. The reaction of the named races to $B t p$, which was recorded in separate tests during pathogen increases, showed that about half the races were virulent to this gene (Table 7). It should be kept in mind that the dwarf bunt tests performed here and elsewhere are all based on an artificial inoculation procedure, and that results from the procedure have not been compared directly with tests under natural field conditions after inoculating the soil surface with teliospores.

In the previous analysis of dwarf bunt races (25), the Bt5 differential used was a hybrid of Elgin and Hohenheimer. However, it was determined later that this hybrid did not fully express the Bt5 resistance of Hohenheimer, and that U.S. dwarf bunt races lacked virulence to $B t 5$ (24). In later studies, workers reverted back to using Hohenheimer as the Bt5 differential in race tests. The two dwarf bunt races D-3 and D-9 were differentiated from each other in the previous analysis only by their reaction to the $B t 5$ hybrid but both are avirulent to Hohenheimer (17). In the current study, these two races also had the same reactions to Bt11 through Bt15 and $B t p$. Thus, it is suggested that the designation D-3 be retained and D-9 dropped unless additional differentials are identified that can differentiate D-3 and D-9 from each other.

Concluding remarks. A common set of differential cultivars that is used internationally is essential for comparison of virulence characteristics of bunt isolates and for a common understanding of useful resistance genes in wheat in various areas of the world that can benefit the development of local bunt-resistant cultivars. The winter habit differential cultivar set Bt1 through Bt13 and Btp developed by R. J. Metzger and J.A. Hoffmann that was used for the current study has a wide international distribution and has been valuable for such purposes. An advantage of using these differentials is that they are morphologically distinguishable from each other for the most part (42), reassuring workers of correct readings. An additional benefit is that the differentials are readily available to international researchers via the United States Department of Agriculture-Agricultural Research Service National Small Grains Collection (NSGC) in Aberdeen, ID. New, useful differentials that might be discovered can be added to those currently used to better define the resistance factors in wheat.

This report illustrates the remarkable level of disease control that can be conferred by single resistance genes where disease can be reduced from over $90 \%$ severity to $0 \%$. The vertical resistance offered by certain single bunt-resistance genes in cultivars has been durable under commercial conditions in the United States. In the 1960 s, dwarf bunt was a serious production problem in areas where the disease was most prevalent in the United States (24). The problem was solved when breeders utilized the genes from PI 178383 in new cultivar releases in the early 1970s, where the resistance comes primarily from $B t 8(35,39)$. This was followed by the release of several other resistant cultivars based on this same resistance, and also the Bt12 resistance gene that originated from CI 14106 or SM22 (18). Cultivars that have resistance genes $B t 8$ or $B t 12$ are still highly effective today for the control of bunt and have eliminated losses caused by dwarf bunt where they are commonly grown. However, the narrow genetic basis for resistance in the United States indicates a vulnerability to new races that might develop.
Screening of more than 20,000 winter wheat accessions from the NSGC in annual dwarf bunt screening nurseries over numerous years has identified several wheat landraces that are highly resistant to a composite of pathogenic races of $T$. contraversa (41). Similarly, over 25,000 accessions from the NSGC have also been screened for common bunt resistance using different composites of pathogenic races of common bunt fungi (40). The few lines that remain highly resistant in repeated experiments are then screened to individual races of common bunt and dwarf bunt fungi in an attempt to elucidate the genes responsible for conferring the resistance (21). Such tests have identified wheat lines that carry known and unknown resistance genes or new combinations of resistance genes that could be useful in cultivar development, including wheat lines that are resistant to the highly virulent races described here (B. J. Goates, unpublished). The resistance characteristics in these wheat lines will be the subject of a future report. There is no doubt that many virulence factors in these bunt fungi and resistance factors in wheat are unknown. The races of common bunt and dwarf bunt fungi described in these studies that have virulence to previously uncompromised individual resistance genes or gene combinations are particularly valuable for identifying resistance factors in wheat. In addition, examination of the response of resistant wheat to the defined pathogenic races may assist the elucidation of unknown virulence factors in the pathogens.

\section{Literature Cited}

1. Aggarwal, P., and Sood, A. K. 2006. Characterization of the bunt isolates collected from dry temperate zone of Himachal Pradesh. Indian Phytopathol. 59:318-322.

2. Andrews, J. A. 1987. The bread wheat races of bunt represented in the Australian bunt collection. Euphytica 36:577-580.

3. Ata Hossaini, S. M., Torabi, M., and Jafarpour, B. 2003. Physiologic races of Tilletia laevis in Khorasan. Seed Plant 18:383-393.

4. Babayants, L. T., Babayants, O. V., Baranovskaya, V. L., and Dubinina, L. A. 2006. Tilletia caries and resistance of wheat to this pathogen in Ukraine. Czech J. Genet. Plant Breed. 42 (Spec. Issue):33-36.

5. Bao, X. 2010. Host specificity and phylogenetic relationships among Tilletia species infecting wheat and other cool season grass. Doctoral dissertation, Washington State University, Pullman.

6. Bao, X., and Carris, L. M. 2009. Common and dwarf bunt of wheat: one or three species? (Abstr.) Phytopathology 99:S8.

7. Blazkova, V., and Bartoš, P. 2002. Virulence pattern of European bunt samples (Tilletia tritici and T. laevis) and sources of resistance. Cereal Res. Commun. 30:335-342.

8. Chauhan, R. S., Sood, A. K., and Singh, B. M. 1994. Relative aggressiveness of new virulences of Tilletia foetida and T. caries on wheat cultivars. Indian Phytopathol. 47:232-235.

9. Dariaee, A., Ghazali Biglar, H., and Haghparast, R. 2006. Identification of new wheat common bunt pathotypes (Tilletia laevis Kühn). Comm. Appl. Biol. Sci. Ghent Univ. 71/3b:1093-1101.

10. Dewey, W. G. 1975. Registration of Hansel wheat. Crop Sci. 15:888.

11. Dewey, W. G. 1981. Registration of Manning wheat. Crop Sci. 21:636.

12. Dumalasová V., and Bartoš, P. 2007. Reaction of winter wheat cultivars to common bunt Tilletia tritici (Bjerk.) Wint. and T. laevis Kühn. Plant Prot. Sci. 43:138-141.

13. Finci, S. 1981. Studies on the pathogenic races of Tilletia foetida and Tilletia caries and their pathogenicity on some wheat varieties in Turkey. EPPO Bull. 11:77-82.

14. Gaudet, D. A., and Puchalski, B. J. 1989. Races of common bunt (Tilletia caries and T. foetida) of wheat in western Canada. Can. J. Plant Pathol. 11:415-418.

15. Gaudet, D. A., and Puchalski, B. J. 1995. Influence of temperature on interaction of resistance genes in spring wheat differentials with races of common bunt Tilletia tritici and T. laevis. Can. J. Plant Sci. 75:745-749.

16. Goates, B. J. 1992. New potential sources of resistance for control of dwarf bunt. Page 6 in: Proc. VIIIth Biennial Workshop Smut Fungi, Athens, GA.

17. Goates, B. J. 1996. Common bunt and dwarf bunt. Pages 12-25 in: Bunt and Smut Diseases of Wheat: Concepts and Methods of Disease Management. R. D. Wilcoxson and E. E. Saari, eds. CIMMYT, Mexico City.

18. Goates, B. J. 1997. Host resistance to dwarf bunt. Pages 317-326 in: Bunts and Smuts of Wheat: An International Symposium. V. E. Malik and D. E. Mathre, eds. North American Plant Protection Organization, Ottawa, ON, Canada.

19. Goates, B. J. 1999. Non-Bt-8 mediated resistance to dwarf bunt in wheat cultivars deriving resistance from PI 178383. (Abstr.) Phytopathology 89:S28.

20. Goates, B. J. 2002. Characterization of a new virulent race of Tilletia controversa. (Abstr.) Phytopathology 92:S30.

21. Goates, B. J. 2004. Resistance genes and sources of resistance for control of 
dwarf bunt of wheat (TCK) caused by Tilletia controversa Kühn. Page 351 in: Proc. 15th Int. Plant Prot. Congr. Beijing.

22. Goates, B. J., and Peterson, G. L. 1999. Relationship between soilborne and seedborne inoculum density and the incidence of dwarf bunt of wheat. Plant Dis. 83:819-824.

23. Griffith, R. B., Zscheile, F. P., and Oswald, J. W. 1955. The influence of certain environmental factors on expression of resistance to bunt in wheat. Phytopathology 45:428-434.

24. Hoffmann, J. A. 1982. Bunt of wheat. Plant Dis. 66:979-987.

25. Hoffmann, J. A., and Metzger, R. J. 1976. Current status of virulence genes and pathogenic races of the wheat bunt fungi in the northwestern USA. Phytopathology 66:657-660.

26. Huber, K., and Buerstmayr, H. 2006. Development of methods for bunt resistance breeding for organic farming. Czech J. Genet. Plant Breed. 42 (Spec. Issue):66-71.

27. Ismail, S. F., Mamluk, O. F., and Azmeh, M. F. 1995. New pathotypes of common bunt of wheat from Syria. Phytopathol. Mediterr. 34:1-6.

28. Ittu, M., Saulescu, N. N., and Ittu, G. 2006. Latest in breeding for resistance to common bunt in Romania. Czech J. Genet. Plant Breed. 42 (Spec. Issue): 15 .

29. Kawchuk, L. M., Kim, W. K., and Nielsen, J. 1988. A comparison of polypeptides from the wheat bunt fungi Tilletia laevis, T. tritici, and T. controversa. Can. J. Bot. 66:2367-2376.

30. Liatukas, Z., and Ruzgas, V. 2008. Resistance genes and sources for the control of wheat common bunt (Tilletia tritici (DC.) Tul.). Biologija 54:274278.

31. Mardoukhi, V., and Torabi, M. 2003. New pathotypes of Tilletia laevis from Iran. Seed Plant 19:14-24.

32. Matanguihan, J. B., and Jones, S. S. 2011. A new pathogenic race of Tilletia caries possessing the broadest virulence spectrum of known races. Plant Health Progress. Online publication. doi:10.1094/PHP-2010-0520-01-RS.
33. Matanguihan, J. B., Murphy, K. M., and Jones, S. S. 2011. Control of common bunt in organic wheat. Plant Dis. 95:92-103.

34. Metzger, R. J., and Hoffmann, J. A. 1978. New races of common bunt useful to determine resistance of wheat to dwarf bunt. Crop Sci. 18:49-51.

35. Peterson, C. J., Vogel, O. A., George, D. W., and Metzger, R. J. 1974. Registration of Luke wheat. Crop Sci. 14:129.

36. Rodenhiser, H. A., and Holton, C. S. 1945. Distribution of races of Tilletia caries and Tilletia foetida and their relative virulence on certain varieties and selections of wheat. Phytopathology 35:955-969.

37. Smith, W. K. 1932. The effect of different temperatures on the reaction of Hope wheat to stinking smut. Phytopathology 22:615-627.

38. Sood, A. K. and Singh, B. M. 1985. Occurrence and distribution of virulences of Tilletia foetida and T. caries causing bunt of wheat in Himachal Pradesh. Indian Phytopathol. 38:695-699.

39. Sunderman, D. W., and Wise, M. 1973. Registration of Franklin wheat Crop Sci. 13:287

40. USDA, ARS, National Genetic Resources Program. 2011. Germplasm Resources Information Network-(GRIN). Online Database for Common Bunt. National Germplasm Resources Laboratory, Beltsville, MD. Online publication. http://www.ars-grin.gov/cgi-bin/npgs/html/desc.pl?65032.

41. USDA, ARS, National Genetic Resources Program. 2011. Germplasm Resources Information Network-(GRIN). Online Database for Dwarf Bunt. National Germplasm Resources Laboratory, Beltsville, MD. Online publication. http://www.ars-grin.gov/cgi-bin/npgs/html/desc.pl?65033.

42. Wächter, R., Waldow, F., Müller, K. J., Spiess, H., Heyden, B., Furth, U., Frahm, J., Weng, W., Miedaner, T., Stephan, D., and Koch, E. 2007. Resistance of winter wheat varieties and breeding lines against common bunt (Tilletia tritici) and dwarf bunt (T. controversa). Nachrichtenbl. Dtsch. Pflanzenschutzdienst (Berlin) 59:S.30-39.

43. Zscheile, F. P. 1966. Photoperiod-temperature-light relationships in development of wheat and bunt. Phytopathol. Z. 57:329-374. 